\title{
Year Round Performance of Different Varieties of Oyster Mushroom (Pleurotus spp.) in the Lakhimpur District of Assam
}

\author{
Himadri Gogoi ${ }^{1}$ *, B.C. Deka ${ }^{2}$,J.K. Dutta ${ }^{2}$, A.Chakraborty ${ }^{2}$ and B. Bora ${ }^{3}$ \\ ${ }^{1}$ ARYA Project, KVK, Lakhimpur, India \\ ${ }^{2}$ KVK, Lakhimpur, India \\ ${ }^{3}$ Biswanath College of Agriculture, Assam Agricultural Unicversity, India \\ *Corresponding author
}

Mushroom cultivation is a highly profitable enterprise with a least cost and high profit combinations. Temperature and relative humidity has large impacts on cultivation of mushroom. Among all the mushrooms Pleurotus spp. are second highest cultivable mushroom in the world. Sub-tropical climates are found suitable for its cultivation. The present study was conducted to evaluate the year round performance of different varieties

\section{Keywords}

ARYA, Oyster mushrooms, Entrepreneurship development

Article Info

Accepted:

15 December 2020

Available Online:

10 January 2021 of oyster mushroom viz. P.ostreatus, P. florida and P. sajor-caju in the Lakhimpur district of Assam under ARYA (Attracting and retaining Youth in Agriculture) project of ICAR implemented by KVK, Lakhimpur. The study comprised of five youth groups under the project. The spawns are obtained from Biswanath College of Agriculture under Assam Agricultural University, Jorhat and Spawn Production Unit of Krishi Vigyan Kendra, Lakhimpur. 120 packets of spawn per unit were provided to each youth groups/unit. Each unit has a capacity to run 240 beds/crop cycle and a total of 4 crop cycle were run at 4 different seasons viz. winter season, summer season, monsoon and post monsoon seasons of the year. All the 3 species of oyster mushrooms performed well throughout the year. The yield of P.ostreatus, P. florida and P. sajor-caju are found to be highest in the post monsoon season. The lowest yield of P. ostreaatus and P. florida was obtained in the summer season (March-May) whereas for P. sajor caju lowest yield was obtained in the monsoon season (June-September). The performance of P. ostreatus was found to be better as compared to the P. florida and P. sajor-caju throughout the year. For the development of entrepreneurship through year round production of oyster mushroom in the Lakhimpur districts of Assam, cultivation of P. ostreatus was found to be more profitable followed by P. sajor-caju .

\section{Introduction}

Mushroom is an edible, fleshy fruiting body of fungus belonging to the subdivision Basidiomycotina with rich in nutritional and medicinal properties. These are saprophytic fungi growing on dead organic matters of vegetative origin and can utilize almost all forest and agricultural residues as substrates (Adejoye et al., 2006). It is considered to be a 
complete, health food and suitable for all age groups, child to aged people. Mushrooms are becoming more important in our diet due to its nutritional value, related to high protein, dietary fibre, vitamin, minerals and low fat / energy contents (Agahar-Murugkar and Subbulakshmi, 2005). It has tremendous health benefits (Table.1) and extensively used in folk medicine. Mushroom cultivation not only helps to reduce the protein deficiency in developing countries like India but also increase the income of the rural poor people (Sharma et al., 2013). It can be a big source of income through rural development programme for farmers if they are made aware its cultivation process and its importance. Besides selling fresh mushroom, the value-added products of mushroom can bring more profit to the farmer's especially rural youth and migrant workers (Wakchaure. G.C.,2014). Among all the cultivated mushrooms Pleurotus spp, commonly known as oyster mushroom (known as 'Dhingri' in India) occupied second position in the world and known for its nutritional and medicinal values (Khan et al., 2008). The word 'Pleuro' is derived from Greek word which means formed laterally or lateral position of the stalk or stem (Mahalakshmi et. al.,2019) Cultivation of Oyster mushroom with agricultural residues, such as rice and wheat straw is a value added process to convert these materials into human food (Pokhrelet al.,2013). Environment and mushroom cultivations both are co-related. Environmental factors such as temperature, humidity, fresh air, light intensity affects the formation, colour and growth rate of mushrooms in many ways (Stamets et. al., 1993). Pleurotus spp are subtropical edible mushroom and very much affected by temperature and relative humidity. It can be grown in wide range of temperature (15$30^{\circ} \mathrm{C}$ ) that varies from species to species (Van Peer et al., 2009 \& Uddin et al., 2011). In the present study, the performance of different varieties of oyster mushrooms viz $P$. ostreatus, $P$. florida and $P$. sajor caju were observed at various seasons in the Lakhimpur district of Assam.

\section{Materials and Methods}

A study was conducted under ARYA (Attracting and Retaining Youth in Agriculture) project of ICAR implemented by Assam Agricultural University (AAU) through KVK, Lakhimpur. Five rural youth groups from Rangati, Karunabari, Bholabori, Gosaichuk and Handohkhowa villages of Lakhimpur district were selected under this project. The cultivation techniques were adopted as per the standard Oyster mushroom cultivation practices (Singh et al., 2011). The spawn of 3 varieties of oyster mushroom viz. Pleurotus ostreatus, Pleurotus florida and Pleurotus sajor-caju were obtained from Biswanath College of Agriculture, under Assam Agricultural University, Jorhat and spawn production unit of Krishi Vigyan Kendra, Lakhimpur. The standard size of the 5 entrepreneurial units in the present work was $15 \mathrm{ft} \times 10 \mathrm{ft} \times 8 \mathrm{ft}$ and all the bags were hanged in a vertical line comprised of total 5 bags per line. The minimum bag to bag distances were maintained and a total of 240 bags were hanged per unit. The temperature and humidity in both inside and outside of the house were recorded by using thermo hygrometer. Data on various parameters viz. fresh yield, dry yield, fresh to dry yield ratio, cost of production, total production, gross return were recorded to evaluate the performance of 3 different varieties of Pleurotu spp. namely $P$. ostreatus, $P$. florida and $P$. sajor-caju throughout the year at four different seasons viz. Post summer (OctoberNovember), Monsoon (June- September), Winter (Dec- February) and summer seasons (March-May). Yield was determined by weighing the fruiting bodies of both fresh and dry mushroom and the total yield was 
determined by adding the yield of 3 flushes of mushroom. The Biological efficiency was determined by adopting the following formula.

Biological efficiency $(\mathrm{BE})=$

Fresh weight of harvested mushrooms

Dry weight of substrate x 100

The average profitability index of each entrepreneurial unit was calculated by estimating the benefit cost ratio (BCR).

\section{Results and Discussion}

The data presented in table 2 revealed that all the 3 species of Pleurotus spp viz. P. ostreatus, $P$. florida and $P$. sajor-caju performed well in all the seasons. However, the fresh yield of all the 3 species of Pleurotus spp was found to be highest in the post-monsoon season (Figure 1). Though the yield performance of all the species are satisfactory at various seasons but the yield of $P$. ostreatus was found to be highest in all the seasons as compared to the $P$. florida and $P$. sajor-caju .

Data presented in table 2 indicated the yield performance of different Pleurotus spp throughout the year. The fresh yield obtained from the total 3 flushes of $P$. ostreatus, $P$. florida and $P$. sajor-caju was recorded in the range from 1420-1480 g/ bed, 1137-1290 $\mathrm{g} / \mathrm{bed}$ and 1147-1280 g/bed, respectively. The $P$. ostreatus and $P$. florida gave the maximum yield (1480 g and $1290 \mathrm{~g}$ ) and lowest yield (1420 g and $1137 \mathrm{~g}$ ) in Post Monsoon season (October-November) and summer season (March-May), respectively whereas, $P$. sajorcaju produced the maximum yield (1280 g and $1270 \mathrm{~g}$ ) in Post Monsoon season (October-November) and winter season (December -January), respectively. $P$. sajorcaju produced lowest yield (1147 $\mathrm{g}$ ) in the
Monsoon season (June-September).

The yield of $P$. ostreatus was found to be higher in all the seasons of the year as compared with the $P$. florida and $P$. sajorcaju (Table 2, Fig 1). Similar observation was also observed by Mahalakshmi et al,(2019) in their study on seasonal performance of oyster mushroom where they found the yield performance of oyster mushroom was poor in the summer season. They have also found lowest primodial fruit bodies in the summer season. Upadhyay et al,(2003) and Tripathi et al., (2005) also reported that the maximum yield of Pleurotus membranaceous in October to January. In the present study, the maximum yield was obtained in the post monsoon season (Oct-Nov) followed by winter season (Dec-Feb) in case $P$. ostreatus and $P$. sajor caju. Das et al,(1991) reported that seasonal variations affect the number, weight, crop production period and yield of mushroom.

The data presented in Table 3 indicated the variations in the biological efficiency among the 3 varieties of oyster mushroom in various seasons. Analysis of data indicates that among the 4 seasons, the biological efficiency of all the 3 varieties viz. P. ostreatus, $P$. florida and P. sajor-caju were found to be highest $(98.06$ $\%, 85.89 \%$ and $85.31 \%$ ), respectively in the post summer season (October-November which recorded the average temperature and relative humidity inside the house of $27^{\circ} \mathrm{C}$ and $82.10 \%$, respectively. The lowest biological efficiency for $P$. ostreatus and $P$. florida were found to be minimum $(94.66 \%$ and $73.55 \%$ ), respectively in the summer season when average temperature and relative humidity inside the house were recorded to be $25.59^{\circ} \mathrm{C}$ and $81.93 \%$, respectively and for $P$. sajor-caju, the minimum $(76.43 \%) \mathrm{BE}$ is found in the monsoon season (JuneSeptember) when average temperature of $27.98^{\circ} \mathrm{C}$ and relative humidity of $82.70 \%$ were recorded inside the house. 
Biological efficiency of all the 3 species was found to be good throughout the year at different seasons although biological efficiency of $P$. ostreatus was found to be highest in all the season. The present findings was in conformity with the findings of Tripathi et al, (2005) who suggested that the better growth of Pleurotus fungus was found in temperature range of $14-27^{0} \mathrm{C}$ with relative humidity of $70-80 \%$.

Data presented in the table 4 revealed that the cost involved in preparation of mushroom bed in all the seasons remains the same for all the 3 species of Pleurotus spp in all the locations. The average production of $P$. ostreatus was found in the ranges from $1.42-1.48 \mathrm{Kg} / \mathrm{bed}$ with average net return ranges from Rs. 249 to Rs. 261/bed in all the four seasons and the average profitability index (B:C ratio) of $P$. ostreatus was found to be highest in the post monsoon season(8.45) followed by winter season (8.34), respectively. The gross return obtained from the production of $P$. ostreatus with 4 crop cycles@ 240 beds/crop cycle were Rs. 70,080, Rs. 68,160, Rs.69,600 and Rs.71,040 in winter, summer, monsoon and post monsoon season, respectively with a total average return of Rs. 2,78,880/year. Similarly, the average production of $P$. florida was also found to be in the ranges from 1.13$1.29 \mathrm{Kg} / \mathrm{bed}$ with average net return ranges from Rs. 191 to Rs. 223/bed in all the four seasons and the average profitability index (B:C ratio) of $P$. florida was found to be highest in the post monsoon season (7.37) followed by monsoon season(6.97),respectively.

The average return from $P$. florida and $P$ sajor-caju were found to be Rs. 2,31,360/year and Rs. 2,34,720/year, respectively with an average cost of Rs. 33,600/year which reaffirmed mushroom cultivation as a least cost and high profit enterprise. Dhondayal, (1989) studied the input output relationship of mushroom based on production function expressed it as a least cost and high profit combinations. Similar observation was also made by Elsamma et al, (2010) in their study and they found a low input to high output ratio in cultivation of oyster mushroom and proved mushroom cultivation as a profitable enterprise which was in conformity with the findings of our present investigation.

Table.1 Moisture content (\%) and Nutritive values of 3 species of Oyster mushrooms $(\mathrm{g} / 100 \mathrm{~g}$ dried sample)

\begin{tabular}{|l|l|l|l|l|l|l|}
\hline $\begin{array}{l}\text { Mushroom } \\
\text { Species }\end{array}$ & $\begin{array}{l}\text { Moisture } \\
(\mathbf{\%})\end{array}$ & $\begin{array}{l}\text { Carbohydrate } \\
\text { (g/100g of } \\
\text { dried sample) }\end{array}$ & $\begin{array}{l}\text { Fibre } \\
\text { (g/100g of } \\
\text { dried } \\
\text { sample) }\end{array}$ & $\begin{array}{l}\text { Protein } \\
\text { g/100g of } \\
\text { dried } \\
\text { sample) }\end{array}$ & $\begin{array}{l}\text { Fat } \\
\text { (g/100g } \\
\text { of dried } \\
\text { sample) }\end{array}$ & $\begin{array}{l}\text { Ash } \\
\text { (g/100g } \\
\text { of dried } \\
\text { sample) }\end{array}$ \\
\hline $\begin{array}{l}\text { Pleurotus. } \\
\text { ostreatus }\end{array}$ & $86.5 \pm 0.8$ & $39.4 \pm 5.9$ & $27.0 \pm 2.2$ & $23.5 \pm 2.9$ & $2.6 \pm 0.2$ & $7.4 \pm 0.9$ \\
\hline $\begin{array}{l}\text { Pleurotus } \\
\text { florida }\end{array}$ & $87.4 \pm 1.1$ & $40.3 \pm 4.5$ & $26.8 \pm 1.9$ & $20.6 \pm 2.6$ & $3.9 \pm 0.2$ & $8.3 \pm 0.2$ \\
\hline $\begin{array}{l}\text { Pleurotus } \\
\text { sajo-rcaju }\end{array}$ & $87.2 \pm 0.5$ & $37.2 \pm 4.2$ & $26.2 \pm 2.0$ & $24.5 \pm 2.9$ & $4.0 \pm 0.6$ & $8.0 \pm 0.3$ \\
\hline
\end{tabular}

(Source: Khan et al., 2008) 
Table.2 Yield performance of $P$. ostreatus, $P$. florida and $P$. sajor- caju in various seasons

\begin{tabular}{|c|c|c|c|c|c|c|c|c|c|c|}
\hline \multirow{2}{*}{$\begin{array}{c}\text { Sl. } \\
\text { No } \\
\text { • }\end{array}$} & \multirow[t]{2}{*}{ Various season } & \multicolumn{3}{|c|}{ P. ostreatus } & \multicolumn{3}{|c|}{ P. florida } & \multicolumn{3}{|c|}{ P. sajor caju } \\
\hline & & 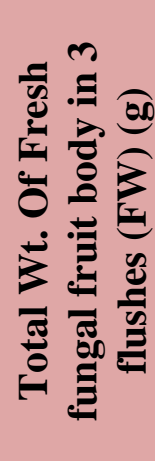 & 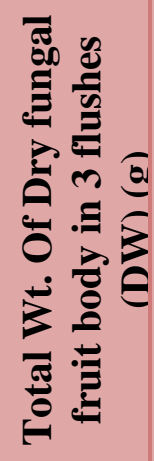 & 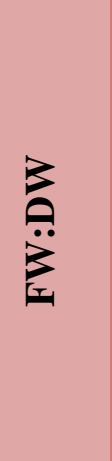 & 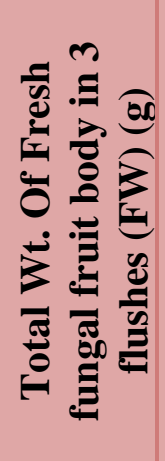 & 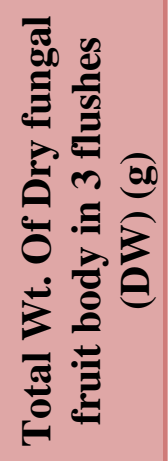 & 荌 & 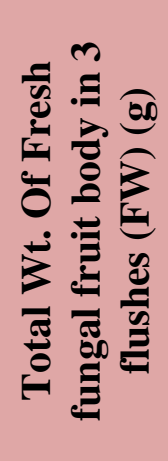 & 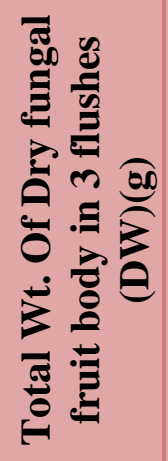 & 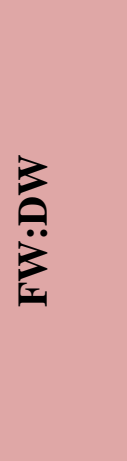 \\
\hline 1. & Winter season & 1460 & 142.30 & 10.26 & 1180 & 109.91 & 10.81 & 1270 & 123.35 & 10.29 \\
\hline 2. & Summer season & 1420 & 137.8 & 10.30 & 1137 & 107.19 & 10.60 & 1190 & 110.53 & 10.76 \\
\hline 3. & Monsoon season & 1450 & 140.7 & 10.31 & 1228 & 120.16 & 10.21 & 1147 & $109 . .27$ & 10.49 \\
\hline 4. & $\begin{array}{c}\text { Post monsoon } \\
\text { season }\end{array}$ & 1480 & 145.96 & 10.13 & 1290 & 121.58 & 10.61 & 1280 & 123.56 & 10.35 \\
\hline
\end{tabular}

Values are average of 5 youth groups selected under ARYA

Table.3 Effect of temperature and relative humidity on biological efficiency of $P$. ostreatus, $P$. florida and $P$. sajor- caju in various seasons

\begin{tabular}{|c|c|c|c|c|c|c|c|}
\hline \multirow[t]{2}{*}{$\begin{array}{l}\text { SL. } \\
\text { No }\end{array}$} & \multirow[t]{2}{*}{ Various Seasons } & \multicolumn{2}{|c|}{$\begin{array}{c}\text { Mean day temperature } \\
\left({ }^{\circ} \mathrm{C}\right) \\
(\mathrm{Sd} \pm \text { Mean })\end{array}$} & \multirow{2}{*}{$\begin{array}{c}\text { Mean } \\
\text { relative } \\
\text { humidity } \\
(\%) \\
(\text { Mean } \pm \text { Sd })\end{array}$} & \multicolumn{3}{|c|}{ Biological efficiency (\%) } \\
\hline & & $\begin{array}{c}\text { Inside } \\
(\text { Mean } \pm \text { Sd })\end{array}$ & $\begin{array}{c}\text { Outside } \\
(\text { Mean } \pm \text { Sd })\end{array}$ & & $\begin{array}{c}P . \\
\text { ostreatus }\end{array}$ & $\begin{array}{c}P . \\
\text { florida }\end{array}$ & $\begin{array}{c}\text { P. sajor } \\
\text { caju }\end{array}$ \\
\hline 1. & Winter season & $24.76 \pm 0.31$ & $27.19 \pm 0.71$ & $79.00 \pm 2.31$ & 97.33 & 78.60 & 84.66 \\
\hline 2. & Summer season & $25.59 \pm 0.49$ & $28.59 \pm 2.47$ & $81.93 \pm 3.84$ & 94.66 & 73.55 & 79.33 \\
\hline 3. & Monsoon season & $27.98 \pm 1.71$ & $31.71 \pm 1.84$ & $82.70 \pm 3.94$ & 96.16 & 81.83 & 76.43 \\
\hline 4. & $\begin{array}{l}\text { Post monsoon } \\
\text { season }\end{array}$ & $27.01 \pm 1.02$ & $30.76 \pm 1.82$ & $82.10 \pm 1.85$ & 98.06 & 85.89 & 85.31 \\
\hline
\end{tabular}

Values are average of 5 youth groups selected under ARYA 
Table.4 Economic analysis of $P$. ostreatus, $P$. florida and $P$. sajor-caju in various seasons

\begin{tabular}{|c|c|c|c|c|c|c|c|c|c|c|c|c|c|c|c|c|}
\hline \multirow{2}{*}{$\begin{array}{l}\text { SI } \\
\text { No }\end{array}$} & \multirow{2}{*}{$\begin{array}{l}\text { Various } \\
\text { Seasons }\end{array}$} & \multicolumn{5}{|c|}{ P. ostreatus } & \multicolumn{5}{|c|}{ P. florida } & \multicolumn{5}{|c|}{ P. sajor caju } \\
\hline & & 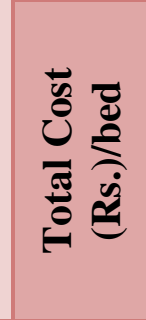 & 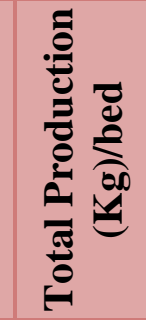 & 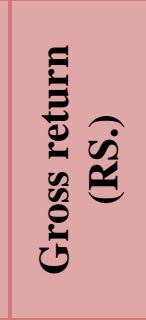 & 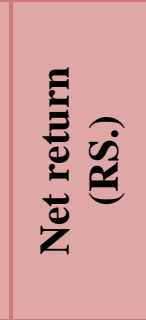 & $\ddot{\ddot{\theta}}$ & 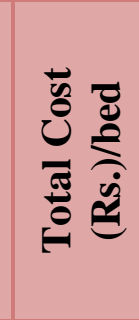 & 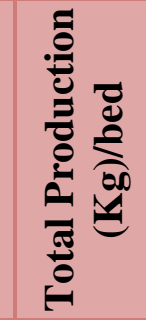 & 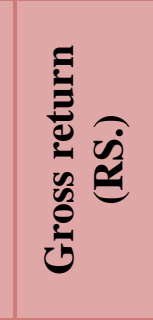 & 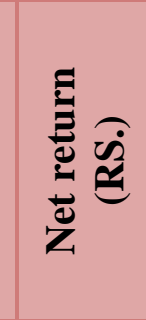 & ف․ & 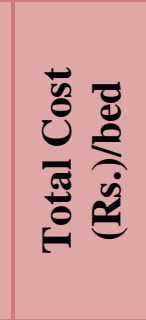 & 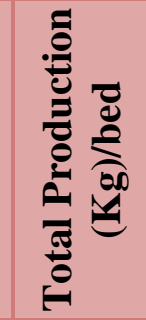 & 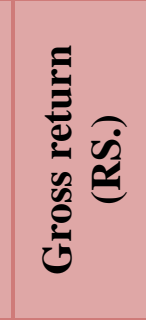 & 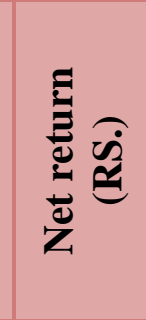 & $\ddot{\varphi}$ \\
\hline 1 & Winter & 35.00 & 1.46 & 292.00 & 257.00 & 8.34 & 35.00 & 1.18 & 236.00 & 201.00 & 6.74 & 35.00 & 1.27 & 254.00 & 219.00 & 7.25 \\
\hline 2 & Summer & 35.00 & 1.42 & 284.00 & 249.00 & 8.11 & 35.00 & 1.13 & 226.00 & 191.00 & 6.45 & 35.00 & 1.19 & 238.00 & 203.00 & 6.8 \\
\hline 3 & Monsoon & 35.00 & 1.45 & 290.00 & 255.00 & 8.28 & 35.00 & 1.22 & 244.00 & 209.00 & 6.97 & 35.00 & 1.15 & 230.00 & 195.00 & 6.57 \\
\hline 4 & $\begin{array}{l}\text { Post } \\
\text { Monsoon }\end{array}$ & 35.00 & 1.48 & 296.00 & 261.00 & 8.45 & 35.00 & 1.29 & 258.00 & 223.00 & 7.37 & 35.00 & 1.28 & 256.00 & 221.00 & 7.31 \\
\hline
\end{tabular}

Values are average of 5 youth groups selected under ARYA 
Figure.1 Fresh yield of Pleurotus spp in various seasons

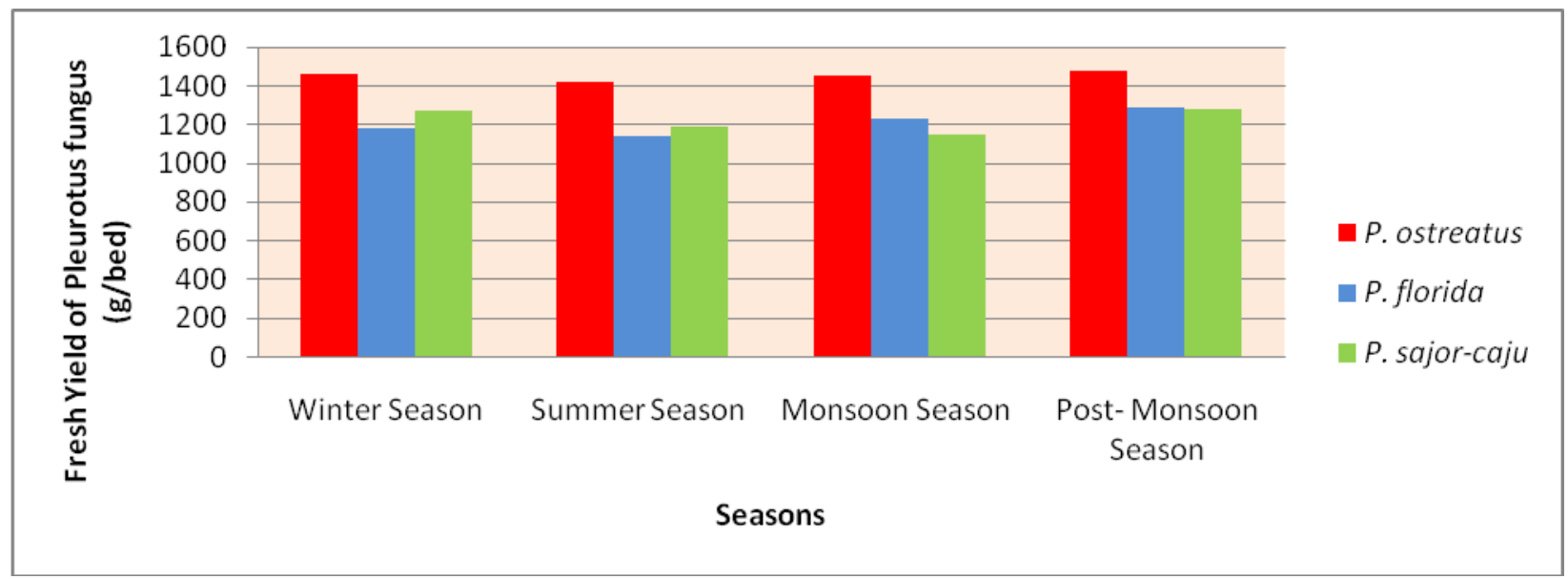

In conclusion, all the 3 species of oyster mushroom viz. $P$. ostreatus, $P$. florida and $P$. sajor-caju performed well in the Lakhimpur district of Assam throughout the year. Out of all, $P$. ostreatus yielded relatively higher than $P$. florida and $P$. sajor-caju in all the seasons . Climatic conditions of the districts are also suitable for the cultivation of oyster mushrooms. Hence, mushroom cultivation could be a promising, profitable agricultural enterprise for the unemployed rural youth of the district.

\section{References}

Adejoye, O. D. Adebayo-Tayo, B. C., Ogunjobi, A. A., and Olaoye, O. A. 2006. Effect of Carbon, Nitrogen and mineral sources on growth of Pleurotusflorida, Nigeria edible mushroom. African Journal of Biotechno-logy, 5:1355-1359.

Agahar-Murugkarand, D., Subbulakshmi, G (2005). Nutritional value of edible wild mushrooms collected from the Khasi hills of Meghalaya. Food Chem, 89:599-603.

Das TK, Sharma R, Singh B, Some Principles in Mushroom Growing and Spawn Mocking. US Department of Agriculture Tech., USA, Bull 1991; 85,
1.

Dhondyal, S.P. 1989. Farm management an economic analysis. Friends Publication, p137-151.

Job, E., \& Geetha, D. (2010). Economic analysis of oyster mushroom production in Kerala. Mushroom Research, 19(2), 94-100.

Khan, A., Alam, N., Amin, R., Ara, I., Shim, M. J., Lee, M. W., \& Lee, T. S. (2008). Nutritional analysis of cultivated mushrooms in Bangladesh-Pleurotus ostreatus, Pleurotus sajor-caju, Pleurotus florida and Calocybe indica. Mycobiology, 36(4), 228-232.

Mahalakshmi, A., Suresh, M., \& Rajendran, S. (2019). Cultivation of oyster mushroom (Pleurotus florida) in various seasons on paddy straw.

Pokhrel, C. P., Kalyan, N., Budathoki, U., Yadav, R. K. P. 2013. Cultivation of Pleurotussajor-caju using different agricultural residues.International Journal of Agricultural Policy and Research 2:19-23.

Pokhrel C. P. Yadav, R. K. P. and Ohga S. 2009.Effects of physical factors and synthetic media on mycelial growth of Lyophyllumdecastes.Journal of Ecobiotech1: 046-050.

Sharma, S. Yadav, R. K. P. and Pokhrel, C. P. 
2013. Growth and Yield of Oyster mushroom (Pleurotus Osteratus0 on different Substrate. Journal of New Biological Reports 2 (1):3-8.

Singh, M., Vijay, B., Kamal, S., \& Wakchaure, G. C. (2011). Mushrooms: cultivation, marketing and consumption. Mushrooms: cultivation, marketing and consumption.

Stamets, P.,1993. Growing gourmetand medicinal mushrooms. A companion guide to the mushroom cultivation. $3 r d$ Edn. Tenspeed Press. California.

Stamets, P. E. (2005). Notes on nutritional properties of culinary-medicinal mushrooms. International Journal of Medicinal Mushrooms, 7(1\&2).

Tripathi DP, Mushroom Cultivation Oxford and IBH Publishing Co. Pvt. Ltd. New Delhi, 2005;pp. 17 and 210.

Uddin, M. N., Yesmin, S., Khan, M. A., Tania, M., Moonmoon, M., \& Ahmed,
S. (2011). Production of oyster mushrooms in different seasonal conditions of Bangladesh. Journal of scientific Research, 3(1), 161-161.

Upadhyay RC, Singh SK, Rai RD, Current Vistas in Mushroom Biology and Production Mushroom Society of India, 2003; pp. 164 and 246.

Van Peer, A. F., Muller, W. H., Boekhout, T., Lugones, L. G., \& Wosten, H. A. (2009). Cytoplasmic continuity revisited: closure of septa of the filamentous fungus Schizophyllum commune in response to environmental conditions. PLoS one, 4(6), e5977.

Wakchaure. G. C. 2011.Mushroomscultivation, marketing and consumption, Chapter: Mushrooms- Value Added Products,pp.233-238.

\section{How to cite this article:}

Himadri Gogoi, B.C. Deka, J.K. Dutta, A. Chakraborty and Bora, B. 2021. Year Round Performance of Different Varieties of Oyster Mushroom (Pleurotus spp.) in the Lakhimpur District of Assam. Int.J.Curr.Microbiol.App.Sci. 10(01): 2368-2375. doi: https://doi.org/10.20546/ijcmas.2021.1001.274 